\title{
Heat stress and occupational health and safety - spatial and temporal differentiation
}

\begin{abstract}
Evidence of climatic health hazards on the general population has been discussed in many studies but limited focus is placed on developing a relationship between climate and its effects on occupational health. Long working hours with high physical activity can cause health problems for workers ranging from mild heat cramps to severe heat stroke leading to death. The paper presents the possible risk of heat hazard to outdoor workers, using the example of Warsaw. The heat stress hazard, defined by $W B G T$ values above 26 and $28^{\circ} \mathrm{C}$ and $U T C l$ above 32 and $38^{\circ} \mathrm{C}$, is assessed from two perspectives: its spatial distribution on a local scale and its temporal changes during the $21^{\text {st }}$ century due to climate change. City centre and industrial districts were identified as the places with the greatest heat stress hazard. The number of heat stress days in a year (as predicted for the $21^{\text {st }}$ century) is increasing, meaning that heat-related illnesses are more likely to have a direct impact on workers' health.
\end{abstract}

\section{Keywords}

Heat stress • occupational health $\bullet U T C l \cdot W B G T \cdot$ Warsaw Agglomeration - climate change

(C) University of Warsaw - Faculty of Geography and Regional Studies

\author{
Krzysztof Błażejczyk ${ }^{1}$, \\ Jarosław Baranowski², \\ Anna Błażejczyk ${ }^{3}$ \\ 1Department of Climatology \\ Institute of Phisical Geography \\ Faculty of Geography and Regional Studies \\ University of Warsaw \\ e-mail: kblazejczyk@uw.edu.pl \\ ${ }^{2}$ Institute of Geography and Spatial Organization \\ Polish Academy of Sciences \\ e-mail: j.bar@twarda.pan.pl \\ ${ }^{3}$ Bioklimatologia. Laboratory of Bioclimatology \\ and Environmental Ergonomics \\ e-mail: anna@blazejczyk.eu \\ Received: 11 October 2013 \\ Accepted: 21 February 2014
}

Introduction

The risk of an organism overheating is an effect of manenvironment heat exchange (Fiala et al. 2012). In hot conditions heat balance is mainly regulated by an increase in sweat evaporation from the body. Evaporative heat loss constitutes $75 \%$ of total heat losses (Fig. 1). It can lead to hazardous health disorders as a result of dehydration. Figure 2 shows an example of sweat rate and total water loss during an exposure of almost 3 hours in the hot dry climate of the Negev Desert (air temperature $35-39^{\circ} \mathrm{C}$ ). The relatively low total water loss (about 1 litre) was the effect of mild activity (2.3 MET) and periodical use of air conditioned spaces (marked by a significant decrease in sweat rate). Such water loss (about $2 \%$ of body weight) produced only thirst and heat fatigue. With a greater loss of water, dehydration symptoms are more dangerous. At $4 \%$ dehydration people may additionally experience a dry mouth. At the next levels of dehydration the following symptoms appear: $6 \%$ - increase in heart rate and body temperature; $8 \%$ - swollen tongue, difficulty speaking, reduced physical and mental performance. At $12 \%$ loss of body weight, recovery is only possible after parenteral fluid administration; $14 \%$ dehydration leads to rapid temperature increase and death. In certain conditions the physiological regulation of body temperature is insufficient to maintain thermal equilibrium or can lead to major health disturbances. In general, skin eruptions, heat fatigue, heat cramps, heat syncope, heat exhaustion and heat stroke are classic heat-related diseases. Most of them are in essence the effects of varying degrees of failure of the thermoregulatory system (Heat-waves: risks and responses, 2004).

Human heat balance is strongly influenced by meteorological factors. Air temperature, solar radiation, air humidity and wind

speed are the main agents in man-environment heat exchange (Fiala et al. 2012). Simultaneously, all these factors are significantly modified by local features of the surroundings (Błażejczyk \& Kunert 2006; Geiger 1969; Kunert 2010; Lee 1978; Oke 1987; Paszyński et al. 1999).

Various indices are utilized to assess the intensity of heat stress. Recent reviews of heat stress indices were carried out by Błażejczyk et al. (2012) and Epstein \& Moran (2006). Heat Index (HI, Rothfusz 1990), Humidex (Masterson \& Richardson 1979), Wet-Bulb Globe Temperature (WBGT, Yaglou \& Minard 1957) and Apparent Temperature (AT, Steadman 1984) are the most widely used simple indices in hot conditions. However, Perceived Temperature (PT, Jendritzky et al. 2011; VDI 2008), Physiological Equivalent Temperature (PET, Mayer \& Höppe 1987), Physiological Subjective Temperature (PST, Błażejczyk 2007; Błażejczyk \& Matzarakis 2007; Błażejczyk \& Twardosz 2010) and Standard Effective Temperature (SET* ${ }^{*}$, Pickup \& de Dear 2000) are new generation indices derived from simple human heat balance models.

The aim of the present paper is to report selected results of the research dealing with assessment of heat stress from the point of view of occupational health and safety. Spatial differentiation on the local scale and temporal changes in the $21^{\text {st }}$ century are discussed.

\section{Methods and materials}

In the present paper, two indices used in occupational health research are applied. The first, the Wet-Bulb Globe Temperature (WBGT), is by far the most widely used heat stress index globally (ISO 7243). It was developed in the US Navy as part of a study on heat-related injuries during military training (Yaglou \& Minard 1957). The WBGT index involves weighting values 


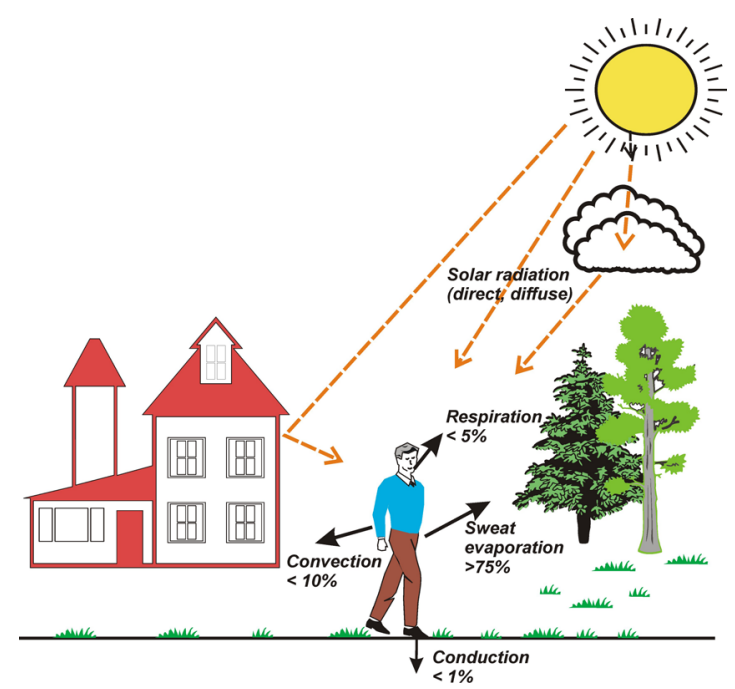

Fig. 1. Manners of heat loss in a hot environment Adapted by authors from: Heat-waves: risks and responses 2004

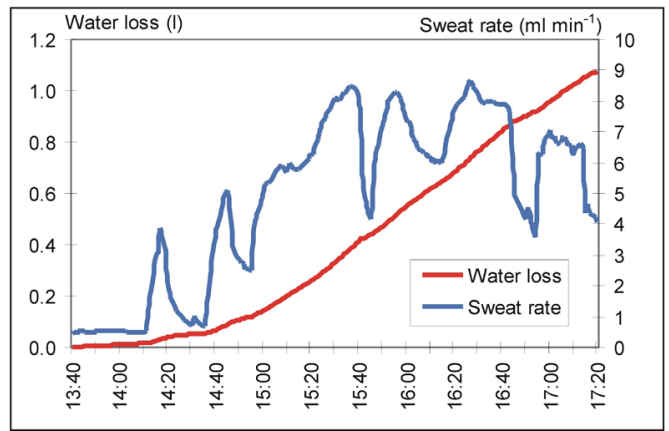

Fig. 2. Changes in sweat rate and total water loss during exposure in the hot dry climate of the Negev Desert (9 Sept 2008); air temperature (Ta) of $35-39^{\circ} \mathrm{C}$, wind speed (v) 2-4 m/s, relative air humidity (RH) $20 \%$, mean radiant temperature $(T m r t) 44-60^{\circ} \mathrm{C}$ Adapted by authors from: Błażejczyk \& Kunert 2011

of the dry-bulb temperature $(T)$, natural (un-aspirated) wet-bulb temperature $\left(T_{n w}\right)$ and black-globe temperature $\left(T_{\text {globe }}\right)$ in the following manner:

$W B G T=0.7 \cdot T_{n w}+0.1 \cdot T+0.2 \cdot T_{\text {globe }}$

Usually the components necessary for the calculation of WBGT are derived from particular measurements with the use of specially designed equipment. A review of equations for the calculation of WBGT on the base of principal meteorological variables was conducted by Lemke \& Kjellstrom (2012). In the present study WBGT was calculated on the basis of standard meteorological variables. Thus, $T_{\mathrm{nw}}$ and $T_{\text {globe }}$ values were approximated by the following equations:

$T_{n w}=-9.27522+0.70196 \cdot T a+0.30338 \cdot v p+0.07823 \cdot R H$

(where Ta is air temperature, $v p$ is actual vapour pressure in $\mathrm{hPa}$ and $R H$ is relative humidity in \%)

$T_{\text {globe }}=2.098-2.561 \cdot v+0.5957 \cdot T a+0.4017 \cdot T m r t$

(where $v$ is wind speed in $\mathrm{m} / \mathrm{s}$ and Tmrt is mean radiant temperature in ${ }^{\circ} \mathrm{C}$ ).

Based on the WBGT index, the American Conference of Government Industrial Hygienists (ACGIH) published the "permissible heat exposure threshold limit values" (TLV), which refer to those heat stress conditions under which nearly all workers may be repeatedly exposed without adverse health effects. These criteria were also adopted by the Occupational Safety and Health Administration (OSHA) and the American Industrial Hygiene Association. The following ranges of WBGT indicate detailed recommendations for outdoor activity (Table 1).

According to Polish legislation acts (PN-EN 27243 2005) assessing the microclimate of work spaces, a WBGT of $26^{\circ} \mathrm{C}$ is assumed to be a hot environment. Therefore, this was the heat stress limit used for the Polish population in the present study.

The second index is the most recently developed, the Universal Thermal Climate Index (UTCl). UTCI is defined as an equivalent ambient temperature (in ${ }^{\circ} \mathrm{C}$ ) of a reference environment that provides the same physiological response for a person as the actual environment (Błażejczyk et al. 2010; Bröde et al. 2012). UTCI is derived from the Fiala multi-node model of human heat transfer and temperature regulation (Fiala et al. 2012). UTCl covers a very wide range of environmental conditions (from extreme cold to extreme heat) and their values are very well correlated with other indices (Błażejczyk et al. 2012). The index is also applicable to occupational health research (Bröde et al. 2013; Kampmann et al. 2012).

The UTCl can be calculated in two different ways. The first method is based on solving Fiala's heat balance model and the second on a regression model. As the direct application of Fiala's multi-node model is time consuming, an approximating 
Table 1. Recommendations for outdoor activity at various WBGT ranges

\begin{tabular}{|c|c|}
\hline WBGT $\left({ }^{\circ} \mathbf{C}\right)$ & Recommendation \\
\hline$<18$ & Unlimited \\
\hline $18-23$ & Keep alert for possible increases in the index and for symptoms of heat stress \\
\hline $23-28$ & Active exercise for non-acclimated persons should be curtailed \\
\hline $28-30$ & Active exercise for all except the well-acclimated should be curtailed \\
\hline$>30$ & All physical activities should be stopped \\
\hline
\end{tabular}

Source: WBGT index 1991

Table 2. UTCl equivalent temperature categorized in terms of thermal stress

\begin{tabular}{|c|c|c|}
\hline $\mathrm{UTCl}\left({ }^{\circ} \mathrm{C}\right)$ range & Stress Category & Physiological responses \\
\hline above 46.0 & extreme heat stress & $\begin{array}{l}\text { Increase in rectal temperature (Tre) time gradient. Steep decrease in } \\
\text { total net heat loss. Averaged sweat rate }>650 \mathrm{~g} / \mathrm{h} \text {, steep increase. }\end{array}$ \\
\hline 38.1 to 46.0 & very high heat stress & $\begin{array}{l}\text { Core to skin temperature gradient }<1 \mathrm{~K} \text { (at } 30 \mathrm{~min} \text { ). Increase in Tre at } \\
\qquad 30 \mathrm{~min} .\end{array}$ \\
\hline 32.1 to 38.0 & high heat stress & $\begin{array}{c}\text { Dynamic Thermal Sensation (DTS) at } 120 \text { min }>+2 \text {. Averaged } \\
\text { sweat rate }>200 \mathrm{~g} / \mathrm{h} \text {. Increase in Tre. Instantaneous change in skin } \\
\text { temperature }>0 \mathrm{~K} / \mathrm{min} \text {. }\end{array}$ \\
\hline 26.1 to 32.0 & moderate heat stress & $\begin{array}{l}\text { Moderate increase in sweat rate, Tre and skin temperature: mean } \\
(T s k m) \text {, face }(T s k f c), \text { hand }(T s k h n) \text {. Occurrence of sweating. Steep } \\
\text { increase in skin wetness. }\end{array}$ \\
\hline 9.1 to +26.0 & no thermal stress & $\begin{array}{c}\text { DTS between }-0.5 \text { and }+0.5 \text { (averaged value). Latent heat loss }>40 \\
\text { W. Plateau in Tre time gradient. }\end{array}$ \\
\hline 0.1 to 9.0 & slight cold stress & DTS < -1. Local minimum of Tskhn (use gloves). \\
\hline-13.0 to 0.0 & moderate cold stress & $\begin{array}{c}\text { DTS }<-2 \text {. Vasoconstriction. Averaged Tskfc }<15^{\circ} \mathrm{C} \text { (pain). Decrease } \\
\text { in Tskhn. Tre time gradient }<0 \mathrm{~K} / \mathrm{h} \text {. Face skin temperature }<15^{\circ} \mathrm{C} \\
\text { (pain). Tmsk time gradient }<-1 \mathrm{~K} / \mathrm{h} \text {. }\end{array}$ \\
\hline-27.0 to -13.1 & high cold stress & $\begin{array}{l}\text { Averaged } T s k f c<7^{\circ} \mathrm{C} \text { (numbness). Tre time gradient }<-0.1 \mathrm{~K} / \mathrm{h} \text {. } \\
\text { Increase in core to skin temperature gradient. }\end{array}$ \\
\hline-40.0 to -27.1 & very high cold stress & $\begin{array}{c}\text { Tskfc }<0^{\circ} \mathrm{C} \text { (frostbite). Steeper decrease in Tre. Tskfc }<7^{\circ} \mathrm{C} \\
\text { (numbness). Occurrence of shivering. Tre time gradient }<-0.2 \mathrm{~K} / \mathrm{h} \text {. }\end{array}$ \\
\hline$<-40.0$ & extreme cold stress & $\begin{array}{l}\text { Tre time gradient }<-0.3 \mathrm{~K} / \mathrm{h} \text {. } \\
\text { Tskfc }<0^{\circ} \mathrm{C} \text { (frostbite). }\end{array}$ \\
\hline
\end{tabular}

Source: adapted from Błażejczyk et al. 2010 and Bröde et al. 2012

regression function has been found (Bröde et al., 2012). The offsets of UTCI to Ta (UTCI-Ta) can be approximated by a polynomial function in Ta, $v, v p$, Tmrt-Ta, including all main effects and interaction terms up to the $6^{\text {th }}$ order. The root mean squared error of approximation is $1.1^{\circ} \mathrm{C} ; 50 \%$ of all observed errors are within $\pm 0.6^{\circ} \mathrm{C}, 80 \%$ within $\pm 1.3^{\circ} \mathrm{C}, 90 \%$ within $\pm 1.9^{\circ} \mathrm{C}$ (Bröde et al., 2012). In the present research this statistical model of UTCI was used. The index was calculated by applying the BioKlima 2.6 software package (http://www.igipz.pan.pl/Bioklima-zgik.html).

While standard meteorological variables can be taken directly from observations, the mean radiant temperature (Tmrt) was calculated using the following equation:

Tmrt $=\left[\left(R^{\prime}+0.5 \cdot L g+0.5 \cdot L a\right) /\left(0.95 \cdot 5.667 \cdot 10^{-8}\right)\right]^{0.25}-273$

where:

$\operatorname{Lg}=5.5 \cdot 10^{-8} \cdot(273+T g)^{4}$

$L a=5.5 \cdot 10^{-8} \cdot(273+T a)^{4} \cdot\left[0.82-0.25 \cdot 10^{(-0.094 \cdot 0.75 \cdot v p)}\right]$

$\mathrm{Tg}$ is temperature of ground surface approximated as follows:

for cloudiness $>=80 \%$

$-T g=T a$

for cloudiness $<80 \%$ and $\mathrm{Ta}>=0^{\circ} \mathrm{C}$

for cloudiness $<80 \%$ and $\mathrm{Ta}<0^{\circ} \mathrm{C}$

$-\mathrm{Tg}=1.25 \cdot \mathrm{Ta}$

$-T g=0.9 \cdot T a$
$R^{\prime}$ is the solar radiation absorbed by a standing human's outer layer of clothing. $R^{\prime}$ was calculated using the statistical SolGlob model developed on the basis of experimental research carried out in various geographical zones, from tropical to sub polar (Błażejczyk 2004, 2005). The model assesses R' based on information regarding global solar radiation (Kglob in $\left.\mathrm{W} \cdot \mathrm{m}^{-2}\right)$, elevation of the Sun $(h S /$ in degrees) and potential global radiation under clear sky conditions $\left(K t\right.$ in $\left.\mathrm{W} \cdot \mathrm{m}^{-2}\right)$. The equations have various forms depending on $\mathrm{hSI}$ and the $\mathrm{Kglob} / \mathrm{Kt}$ ratio:

- for $h S /<=12^{\circ}$,

$R^{\prime}=\left(0.0014 \cdot \mathrm{Kglob}^{2}+0.476 \cdot \mathrm{Kglob}-3.8\right)$

- for $h S I>12^{\circ}$ and a Kglob/Kt ratio <= 0.8

$R^{\prime}=0.2467 \cdot \mathrm{Kglob}^{0.9763}$

- for $h S I>12^{\circ}$ and a $\mathrm{Kg} / \mathrm{lob} / \mathrm{Kt}$ ratio between 0.8 and 1.05

$R^{\prime}=3.6922 \cdot \mathrm{Kglob}^{0.5842}$

- for $h S I>12^{\circ}$ and a $\mathrm{Kglob} / \mathrm{Kt}$ ratio between 1.05 and 1.2

$R^{\prime}=43.426 \cdot \mathrm{Kglob} b^{0.2326}$

- for $h S I>12^{\circ}$ and a $\mathrm{Kglob} / \mathrm{Kt}$ ratio more than 1.2

$R^{\prime}=8.9281 \cdot \mathrm{Kglob}^{0.4861}$. 

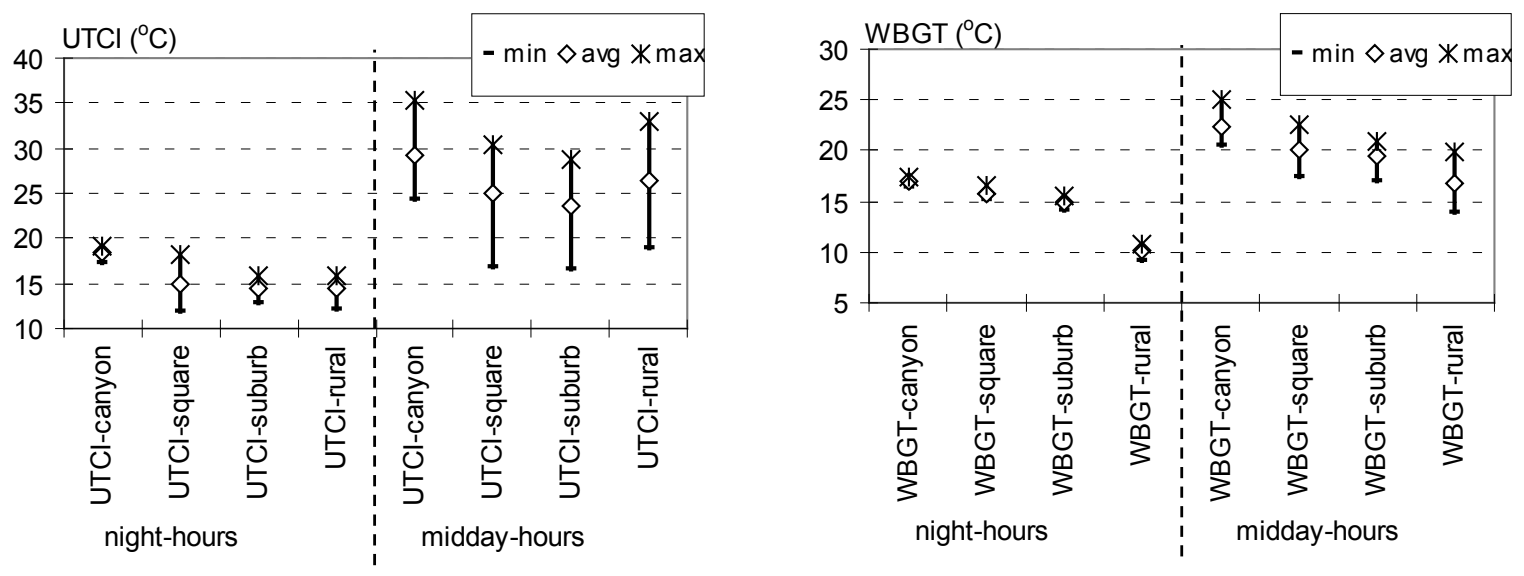

Fig. 3. Mean (avg), minimum (min) and maximum (max) UTCI and WBGT values in night and midday hours of hot summer days (July 2002) in various urban structures in Warsaw; Ta from $12^{\circ} \mathrm{C}$ (nights) to $25^{\circ} \mathrm{C}$ (midday), $v-2-6 \mathrm{~m} / \mathrm{s}, \mathrm{Tmrt}-12-45^{\circ} \mathrm{C}, \mathrm{RH}-60-80 \%$ Source: own elaboration

The UTCI is categorised in terms of thermal stress (Table 2).

In the assessment of spatial differentiation of heat stress, the micro meteorological data collected during field campaigns in the Warsaw Agglomeration in July 2002 and June 2003 were applied. The measurements of air temperature and humidity, wind speed and global solar radiation were carried out in several urban and suburban structures. In July 2002 the measurements covered a street canyon, a square, suburban settlements and a rural area. In June 2003 the observations were carried out in a suburban recreational area, a post representing a lake beach, a pine forest and recreational settlements.

For the assessment of temporal changes in heat stress in the Warsaw Agglomeration in the $21^{\text {st }}$ century, the meteorological elements necessary for the calculations of WBGT and UTCI for the period 2000-2100 were applied. These were based on the MPI-M-REMO regional climate model with a spatial resolution of $25 \times 25 \mathrm{~km}$. Simulations used boundary conditions proposed in the ECHAM5 Global Climate Model for emission scenario A1B (Special Report on Emissions Scenarios, 2000). The A1B emission scenario considers a relatively mild increase in GHGs this century, and is used frequently in climate change predictions. In the present study, the daily meteorological data for air temperature, wind speed, relative air humidity and global solar radiation (simulated for all days of the period 2001-2100) were used in calculations of WBGT and UTCI. The data were extracted for the Warsaw Agglomeration, which covers two E-OBS (European Climate Assessment \& Dataset 2013) grid squares. The data were processed at the Interdisciplinary Centre for Mathematical and Computational Modelling (ICM) at the University of Warsaw by Dr. M. Liszewska, within the framework of the KLIMADA project, using simulations provided by the EU ENSEMBLES project (The ENSEMBLES project RT3 2013).

The temperature data used in the present research, taken from MPI-M-REMO-ECHAM5, fit very well with reference data derived from ERA40 reanalysis (the correlation coefficient is 0.98). For daily values, agreement between modelled and reference data is only slightly weaker, and the correlation coefficient is 0.95 (Liszewska et al. 2012).

In the present paper the frequencies of occurrence of UTCI and WBGT categories indicate the level of heat stress hazard for people working outdoors. For UTCI the frequency of at least high heat stress $\left(U T C />32^{\circ} \mathrm{C}\right)$ and 'very high heat stress' $\left(U T C />38^{\circ} \mathrm{C}\right)$ is considered. For WBGT the days with midday values $>26^{\circ} \mathrm{C}$
(Polish legislation) and $>28^{\circ} \mathrm{C}$ (international legislation, Schulte \& Chun 2009), i.e. days when active exercise should be curtailed, are ascertained and analysed.

\section{Results}

Heat stress in various types of land use

The greatest modification of meteorological conditions and heat stress is observed in urban areas. Figures 3 and 4 show UTCI and WBGT distribution in particular types of land use in the Warsaw Agglomeration. The first example represents three urban structures (a street canyon, a square partially shaded by trees and a suburban villa settlement) in comparison with a rural area outside the city. Sunny warm summer days were chosen. The highest UTCI from the whole day was observed in the central street canyon. During the midday hours $U T C I$ can reach $36^{\circ} \mathrm{C}$, which indicates high heat stress. WBGT values only reached about $25^{\circ} \mathrm{C}$, which indicates moderate heat stress. In the shaded square and suburban districts UTCI values were considerably lower compared to both the street canyon and the rural area, due to groups of trees. The WBGT index is less sensitive to incoming solar radiation and its values do not reflect differences in shading at the observational posts (Fig. 3).

The second example represents a recreational area close to the city. Measurements were taken at a lake beach, a residential area $30 \mathrm{~m}$ from the beach and a forest $200 \mathrm{~m}$ from the beach. Again, the highest $\mathrm{UTCl}$ (up to $32^{\circ} \mathrm{C}$, high heat stress) and WBGT were observed within the settled area. In the forest (due to weak solar radiation) and especially at the lake beach (due to a strong wind), UTCI was significantly lower and did not exceed the zone of thermal neutrality. In the forest, in particular during short periods of solar ray penetration under the tree canopies, $U T C /$ reached the level of moderate heat stress. The WBGT does not include wind speed, so its values are significantly lower in comparison to UTCI (Fig. 4).

The results show microclimatic relations across the studied sites. The meteorological conditions on the days chosen for the present analysis were not very severe. In the case of warmer conditions (with air temperature above $30^{\circ} \mathrm{C}$ ), which can occur in Warsaw in the summer, we should expect higher heat stress. In street canyons and urban squares UTCI and WBGT can reach the highest levels of heat stress. A similar increase in high heat stress can be found inside residential settlements in lakeshore recreational districts. 

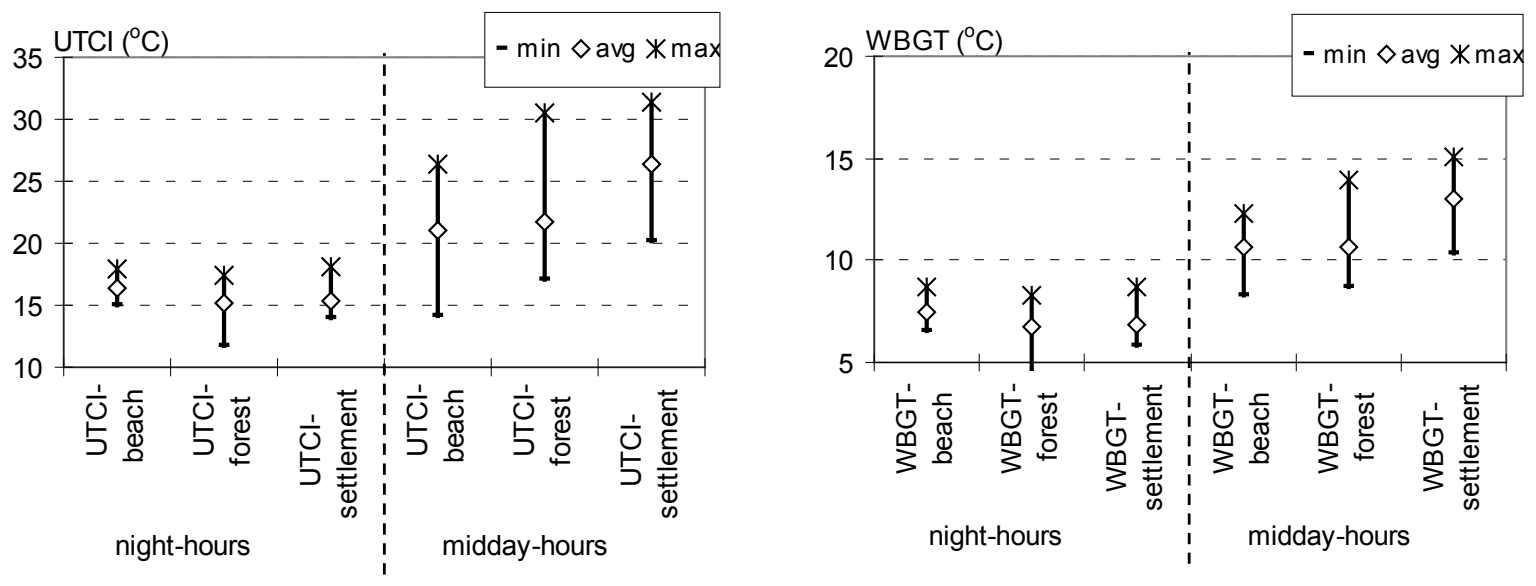

Fig. 4. Mean (avg), minimum (min) and maximum (max) UTCI and WBGT values in night and midday hours of warm summer days (June 2003) in various recreational structures in Warsaw; Ta from $12^{\circ} \mathrm{C}$ (nights) to $25^{\circ} \mathrm{C}$ (midday), $v-2-4 \mathrm{~m} / \mathrm{s}, \mathrm{Tmrt}-12-30^{\circ} \mathrm{C}$, $\mathrm{RH}-60-80 \%$

Source: own elaboration

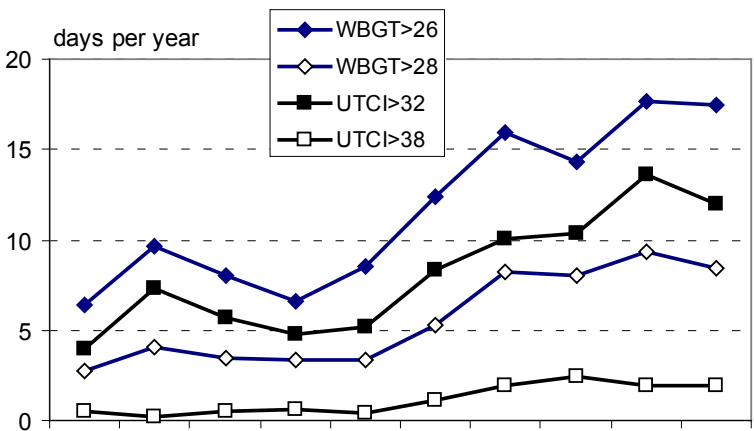

2001- 2011- 2021- 2031- 2041- 2051- 2061- 2071- 2081- 20912010202020302040205020602070208020902100

Fig. 5. Changes of particular categories of heat stress due to UTCI and WBGT indices in consecutive decades of the $21^{\text {st }}$ century

Source: own elaboration

Prediction of heat stress in the $21^{\text {st }}$ century

Simulations of meteorological variables provided by the MPIM-REMO-ECHAM5 climate model for emission scenario A1B show an increase in air temperature, especially in the second half of the $21^{\text {st }}$ century. Such an increase in air temperature is also manifested in the rising trend of heat stress indices. In the first decade of the $21^{\text {st }}$ century the mean annual frequencies of occurrence of the UTCI categories under consideration were of the order of 4 heat stress days $\left(U T C />32^{\circ} \mathrm{C}\right)$ and 0.5 days (UTC/>38 ${ }^{\circ} \mathrm{C}$ ). Using WBGT the frequency of the category $>26^{\circ} \mathrm{C}$ is about 6 days a year and approximately 3 days a year for WBGT $>28^{\circ} \mathrm{C}$.

This significant increase in the frequency of occurrence of the discussed UTCI and WBGT index categories will begin in the middle of the century (the decade 2051-2060). In the last decade of the $21^{\text {st }}$ century the number of heat stress days will be 2-3 times higher than presently. We should expect 12 days a year with $U T C />32^{\circ} \mathrm{C}$ and 2 days annually with $U T C />38^{\circ} \mathrm{C}$. A similar increasing tendency is observed when considering the WBGT index. The number of days with $W B G T>26^{\circ} \mathrm{C}$ will rise to about 18 a year, $W B G T>28^{\circ} \mathrm{C}$ to approximately 9 annually. The relative decrease in the frequency of heat stress days in the decades 2021-2030 and 2031-2040 is an effect of the general decrease in air temperature predicted for those periods (Fig. 5).

While a large degree of year-on-year variability is to be noted in the detailed picture of changes in annual frequency of heat stress days in the discussed UTCI and WBGT categories, it is nevertheless possible to note a statistically significant upward trend for the number of heat stress days over time. The predicted rate of increase in number of days with $U T C I>32^{\circ} \mathrm{C}$ is about 0.9 for each decade of the century, while the anticipated increase in the number of days with $W B G T>26^{\circ} \mathrm{C}$ is about 1.3 per decade.

\section{Discussion}

Up until now the spatial distribution of WBGT on a local scale has not been investigated. The index has usually been used to evaluate heat stress risk in individual work places (Kampmann et al. 2012) and has not been presented on maps. The main reason for this is that the index construction is addressed towards indoor spaces. Only a few researchers have tried to adapt WBGT for outdoor climate conditions (Adelio \& Divo 2009; Bernard \& Pourmoghani 1999; Liljegren etal. 2008). However, these authors have concentrated on the theoretical background of index re-construction and did not discuss the spatial distribution of the index.

By contrast, UTCI has been applied in several research studies to assess its spatial distribution on a local scale. Kunert (2010) modelled UTCI for urban areas based on topoclimatic information for particular types of landscape. She found that, during hot, humid, calm and sunny weather, UTCI varied from about $31^{\circ} \mathrm{C}$ (moderate heat stress) in forests to $48^{\circ} \mathrm{C}$ in city centres and $52^{\circ} \mathrm{C}$ (extreme heat stress) in industrial areas. During cloudy, hot, humid and calm weather we should expect UTCI to range from $30^{\circ} \mathrm{C}$ (moderate heat stress) in forests to $50^{\circ} \mathrm{C}$ (extreme heat stress) in industrial districts. Similar results were obtained by Błażejczyk (2011) and Błażejczyk et al. (2013) who applied the GIS system to generate UTCI maps for Warsaw in various weather scenarios. Again, the parts of Warsaw with the highest heat stress were the densely settled and urbanised areas. An increased risk of heat stress was also observed by Milewski (2013) in urbanised areas and on south-facing slopes in the mountain region of Ziemia Kłodzka.

Only a few researchers have tried to simulate forecasted changes in heat stress due to climate change. Cheung \& Hart (2012) simulated the frequency of days with UTCI category $>32^{\circ} \mathrm{C}$ in the 
$21^{\text {st }}$ century in Hong Kong. They found roughly a $5 \%$ increase in heat stress days in the later decades of the century in comparison with the reference period 1971-2000. However, Błażejczyk \& Błażejczyk (2013) found roughly a $20 \%$ increase in days with the $\mathrm{UTCl}$ category of high heat stress in Central Poland (from 50 to 60 days per year).

\section{Conclusions}

Meteorological conditions continuously influence the human organism. While indoors the microclimate of working spaces can be monitored and ameliorated by heating, cooling or ventilating, outdoors we can only monitor the microclimate of specific places. During hot weather people working outdoors are at great risk of overheating. The overheating risk is caused by both a stressful microclimate and by workload. In such conditions, the physiological processes of thermoregulation may be insufficient to expedite heat from the body to the atmosphere.

Micrometeorological and biothermal conditions in outdoor working spaces are influenced not only by general weather factors but also by specific features of the local environment Additional heat stress input is stimulated by urbanized and industrial areas as well as by the southern exposure of slopes and heating properties of the ground surface (e.g. dry sand, concrete). By contrast, forests and parks, as well as river banks and water body shores, mitigate heat stress.

To protect people working outdoors against heat stress risk, employers must monitor current weather conditions and support workers in hazardous situations by encouraging the drinking of water and the use of shading screens, water curtains or mechanical ventilation. However, in extreme conditions, periodical breaks in work and the use of air-conditioned rooms may be necessary.

The need for such protective actions will increase considerably in the $21^{\text {st }}$ century. The forecasted changes in climate components, mainly in air temperature, will bring about more and more changes in heat stress days.

\section{Acknowledgements}

The studies reported here were supported by a grant from the Polish National Centre for Research (NCN): Nos. 2011/01/B/ ST10/06972 "Assessment of climate change impacts on population health in various regions of Poland and predictions to 2100 " as well as by the EU Central Europe Programme in the framework of the UHI project "Development and application of mitigation and adaptation strategies and measures for counteracting the global Urban Heat Islands phenomenon (UHI)".

Simulations of climate variables used for the calculations of UTCI were made within the framework of the KLIMADA project "Preparing and entering Adaptation Strategies for sectors vulnerable to climate change" led by the Institute of Environment Protection and financed by the Ministry of Environment and the National Fund for Environment Protection and Water Management.

\section{References}

Adélio, RG \& Divo, AQ 2009, 'Physical modelling of globe and natural wet bulb temperatures to predict WBGT heat stress index in outdoor environments', Int J Biometeorol, vol. 53 pp. 221-230.

Bernard, TE \& Pourmoghani, M 1999, 'Prediction of Workplace Wet Bulb Global Temperature', Applied Occupational and Environmental Hygiene, vol. 14, pp. 126-134.

Błażejczyk, K 2004, 'Radiation balance in man in various meteorological and geographical conditions', Geographia Polonica, vol. 77, no. 1, pp. 63-76.

Błażejczyk, K 2005, 'Radiation balance of different segments of the human body', DWD, Annalen der Meteorologie, vol. 41, no. 1, pp. 313-316.

Błażejczyk, K 2007, 'Multiannual and seasonal weather fluctuations and tourism in Poland', in Climate Change and Tourism Assessment and Copying Strategies, eds B Amelung, K Błażejczyk \& A Matzarakis, Institute of Geography and Spatial Organization Polish Academy of Sciences, Maastricht-Warsaw-Freiburg, pp. 69-90.

Błażejczyk, K 2011, 'Mapping of UTCl in local scale (the case of Warsaw)', Prace i Studia Geograficzne WGSR UW, vol. 47, pp. 275-283.

Błażejczyk, K \& Błażejczyk, A 2013, 'Climate change and heat stress in the 21st century - an example from Poland', in Proceedings of the 15th International Conference on Environmental Ergonomics, 11-15th February, Queenstown New Zealand, eds JD Cotter, SJE Lucas \& T Mundel, Queenstown, International Society for Environmental Ergonomics, pp. 31-33.

Błażejczyk, K, Bröde, P, Fiala, D, Havenith, G, Holmér, I, Jendritzky, G, Kampmann, B \& Kunert, A 2010, 'Principles of the new Universal Thermal Climate Index (UTCI) and its application to bioclimatic research in European scale', Miscelanea Geographica, vol. 14, pp. 91-102.

Błażejczyk, K, Epstein, Y, Jendritzky, G, Staiger, H \& Tinz, B 2012, 'Comparison of UTCI to selected thermal indices', Int J Biometeorol, vol. 56, pp. 515-535.
Błażejczyk, K \& Kunert, A 2006, 'Differentiation of bioclimatic conditions of urban areas (the case of Poland)', in $6^{\text {th }}$ International Conference on Urban Climate, Preprints, June 12-16 2006, Göteborg, Sweden, Göteborg University, pp. 213-216.

Błażejczyk, K \& Kunert, A 2011, 'Bioklimatyczne podstawy rekreacji i turystyki w Polsce, 2 wydanie' (Bioclimatic principles of recreation and tourism in Poland, 2nd edition), Monografie IGiPZ PAN, vol. 14.

Błażejczyk, K, Lindner-Cendrowska, K \& Błażejczyk, A 2013, 'Assessment of heat stress at various outdoor spaces in the city (an example from Warsaw)', in Proceedings of the 15th International Conference on Environmental Ergonomics, 1115th February, Queenstown, New Zealand, eds JD Cotter, SJE Lucas \& T Mundel, Queenstown, International Society for Environmental Ergonomics, pp. 211-214.

Błażejczyk, K \& Matzarakis, A 2007, 'Assessment of bioclimatic differentiation of Poland based on the human heat balance', Geographia Polonica, vol. 80, no. 1, pp. 63-82.

Błażejczyk, K \& Twardosz, R 2010, 'Long-Term Changes of Bioclimatic Conditions in Cracow (Poland)', in The Polish Climate in the European Context: An Historical Overview, eds R Przybylak, R Majorowicz, J Brázdil \& M Kejna, Springer, Science + Business Media B.V. pp. 235-246

Bröde, P, Fiala, D, Błażejczyk, K, Holmér, I, Jendritzky, G, Kampmann, B, Tinz, B \& Havenith, G 2012, 'Deriving the operational procedure for the Universal Thermal Climate Index (UTCl)', Int J Biometeorol, vol. 56, pp. 481-494.

Bröde, P, Błażejczyk, K, Fiala, D, Havenith, G, Holmér, I, Jendritzky, G, Kuklane, K \&, Kampmann, B 2013, 'The Universal Thermal Climate Index UTCI Compared to Ergonomics Standards for Assessing the Thermal Environment', Industrial Health, vol. 51, no. 1, pp. 16-24.

Cheung, CSC \& Hart, M 2012, 'Climate change and thermal comfort in Hong Kong', Int J Biometeorol, DOI.10.1007/ s00484-012-0608-9. 
The ENSEMBLES project RT3, 2013. Available from: <http:// ensemblesrt3.dmi.dk> [5 Oct. 2013].

Epstein, Y \& Moran, DS 2006, 'Thermal comfort and heat stress indices', Indust Health, vol. 44, pp. 388-398.

European Climate Assessment \& Dataset, 2013. Available from: $<$ http://eca.knmi.nl/> [5 Oct. 2013].

Fiala, D, Havenith, G, Bröde, P, Kampmann, B \& Jendritzky, G 2012, 'UTCI-Fiala multi-node model of human heat transfer and temperature regulation', Int J Biometeorol, vol. 56, pp. 429-441.

Geiger, R 1969, 'Topoclimates', in World Survey of Climatology, vol. 2, General Climatology, 2, eds HE Landsberg \& H Flohn, Elsevier Publishing Company Amsterdam-London-New York, pp. 105-138.

Heat-waves: risks and responses, 2004, Health and Global Environmental Change, SERIES, no. 2, WHO, Geneva.

ISO 7243 1989, 'Hot environments; estimation of the heat stress on working man, based on the WBGT-index (wet bulb globe temperature)', International Organisation for Standardisation, Geneva.

Jendritzky, G, Staiger, H, Bucher, K, Graetz, A \& Laschewski, G 2011, 'The perceived temperature. The method of the Deutscher Wetterdienst for the assessment of cold stress and heat load for the human body', Deutscher Wetterdienst. Available from: <http://www.utci.org/isb/documents/ perceived_temperature.pdf> [5 Oct. 2013].

Kampmann, B, Bröde, P \& Fiala, D 2012, 'Physiological responses to temperature and humidity compared to the assessment by UTCI, WGBT and PHS', Int J Biometeorol, vol. 56, pp. 505-513.

Kunert, A 2010, 'Modeling of UTCl index in various types of landscape', in Proceedings of the 7th Conference on Biometeorology, eds A Matzarakis, $\mathrm{H}$ Mayer \& FM Chmielewski, Berichte des Meteorologischen Instituts der Albert-Ludwigs-Universität Freiburg, no. 20, pp. 302-307.

Lee, R 1978, Forest Microclimatology. Columbia University Press, New York.

Lemke, B \& Kjellstrom, T 2012, 'Calculating workplace WBGT from meteorological data. A tool for climate change assessment', Industrial Health, vol. 50, pp. 267-278

Liljegren, JC, Carhart, RA, Lawday, P, Tschopp, S \& Sharp, R 2008, 'Modeling the wet bulb globe temperature using standard meteorological measurements', Journal of Occupational and Environmental Hygiene, vol. 5, pp. 645655

Liszewska, M, Konca-Kędzierska, K \& Jakubiak, B 2012, 'Opracowanie scenariuszy zmian klimatu dla Polski i wybranych regionów', (Development of climate change scenarios for Poland and selected regions), Manuscript, Interdisciplinary Centre for Mathematical and Computational Modelling (ICM) of the University of Warsaw.
Masterson, J \& Richardson, FA 1979, Humidex, a method of quantifying human discomfort due to excessive heat and humidity, Downsview, Ontario, Environment Canada.

Mayer, H \& Höppe, P 1987, 'Thermal comfort of man in different urban environments', Theor Appl Climatol, vol. 38, pp. 4349.

Milewski, P 2013, 'Application of the UTCI to the local bioclimate of Poland's Ziemia Kłodzka region', Geographia Polonica, vol. 86, 1, pp. 47-54.

Oke, TR 1987, Boundary layer climates (second edition), Methuen, London-New York.

Paszyński, J, Miara, K \& Skoczek, J 1999, 'Wymiana energii między atmosferą a podłożem jako podstawa kartowania topoklimatycznego', (Energy exchange between atmosphere and earth surface as a basis of topoclimatic mapping), Dokumentacja Geograficzna, vol. 14.

Pickup, J \& de Dear, R 2000, 'An outdoor thermal comfort index (OUT_SET*) - Part I - The model and its assumptions', in Biometeorology and urban climatology at the turn of the millenium. Selected papers from the conference ICBICUC'99, Sydney, [8-12 Nov. 1999], eds R de Dear, J Kalma, T Oke \& A Auliciems, WMO, Geneva, WCASP-50, pp. 279283.

PN-EN 27243 2005, 'Środowiska gorące. Wyznaczanie obciążenia termicznego działającego na człowieka podczas pracy, oparte na wskaźniku WBGT'.

Rothfusz, LP 1990, The heat index equation, NWS Southern Region Technical Attachment, SR/SSD 90-23, Fort Worth, Texas.

Schulte, PA \& Chun, HK 2009, 'Climate change and occupational safety and health. Establishing a preliminary framework', Journal of Occupational and Environmental Hygiene, vol. 6, pp. 542-554.

Special Report on Emissions Scenarios 2000, Cambridge University Press.

Steadman, RG 1984, 'A universal scale of apparent temperature', J Appl Meteorol Climatol, vol. 23, pp. 1674-1687.

WBGT index, 1991. Available from: <http://www.bom.gov.au/info/ wbgt/wbgtrecs.shtml> [5 October 2013].

VDI (2008) 'VDI Guideline 3787 / Part 2: Environmental meteorology: Methods for the human biometeorological evaluation of climate and air quality for urban and regional planning at regional level. Part I: Climate', VDI/DIN-Handbuch Reinhaltung der Luft, Band $1 \mathrm{~B}$, Umweltmeteorologie, Beuth Verlag, Berlin.

Yaglou, CP \& Minard, D 1957, 'Control of heat casualties at military training centers', Am Med Ass Arch Ind HIth, vol. 16, pp. 302-316. 